This pdf of your paper in Urban Landscape Survey belongs to the publishers Oxbow Books and it is their copyright.

As author you are licenced to make up to 50 offprints from it, but beyond that you may not publish it on the World Wide Web until three years from publication (May 2015), unless the site is a limited access intranet (password protected). If you have queries about this please contact the editorial department at Oxbow Books (editorial@oxbowbooks.com). 


\section{URBAN LANDSCAPE SURVEY IN ITALY AND THE MEDITERRANEAN}





\section{An offprint from \\ Urban Landscape Survey in Italy and the Mediterranean}

Edited by

Frank Vermeulen, Gert-Jan Burgers, Simon Keay and Cristina Corsi

In co-operation with

The British School at Rome

Academia Belgica

Koninklijk Nederlands Instituut Rome

Ghent University, Department of Archaeology

Universidade de Évora, CIDEHUS

Within the framework of

Programme 'People' - Marie Curie Action: 'Industry-Academia Partnerships and Pathways'

(FP7-PEOPLE-IAPP - 2008 - Grant Agreement n. 230679)

Project RADIO-PAST: Radiography of the past. Integrated non-destructive approaches to understand and valorise complex archaeological sites

ISBN 978-1-84217-486-9
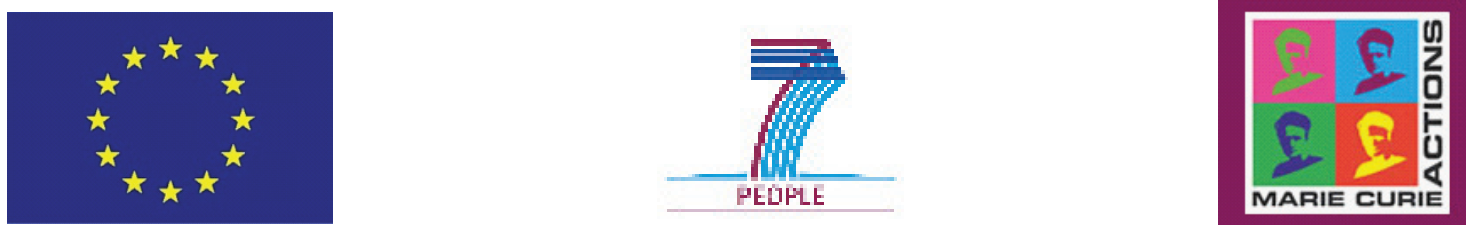

(C) Oxbow Books 2012

www.oxboxbooks.com 


\section{Contents}

List of contributors vii

Introduction. ix

Frank Vermeulen, Gert-Jan Burgers, Simon Keay, Cristina Corsi

\section{PART 1: INTRA-URBAN SURVEY \\ Pre-Roman SITE-PLANNING}

1 Intensive On-site Artefact Survey and Proto-urbanization, Case Studies from Central and South Italy 1 P. Attema and T. de Haas

2 Urban Landscape Surveys on the Salento Isthmus, Italy 13 G.-J. Burgers

\section{TOWNS IN A 'TRANSITIONAL PHASE'}

3 Amiternum and the Upper Aterno-valley: Approaching a Sabine-Roman Town and its Territory M. Heinzelmann and D. Jordan

4 Paestum romana. Problemi di interpretazione e strategie di intervento M. Cipriani and A. Santoriello

5 Contemporary Issues in Surveying Complex Urban Sites in the Mediterranean Region: The example of the city of Thespiai (Boeotia, Central Greece).

J. Bintliff

6 Towards Integrated Non-invasive Research on Complex Urban Sites: Ljubljana Research in Tanagra and Beyond.

B. Slapšak

7 Strategies and Results of the Urban Survey in the Upper City of Ephesus S. Groh

8 Indagini multidisciplinari per la ricostruzione del paesaggio urbano: ricerche sulla topografia antica di Hierapolis di Frigia .

G. Scardozzi

9 The Integrated Urban Survey at Sagalassos .....

F. Martens, B. Mušič, J. Poblome and M. Waelkens

\section{THE ROMAN APPROACH TO TOWNSCAPES}

10 Progetto 'Ager Aquinas'. Indagini aerotopografiche finalizzate allo studio della città romana di Aquinum (Lazio, Italia)

G. Ceraudo

11 Teano (Teanum Sidicinum), Campania

S. Hay, S. Keay and M. Millett

12 Geophysical Prospection in the Vesuvian Cities

J. Ogden, G. Tucker, S. Hay, S. Kay, K. Strutt, S. Keay, D. Camardo and S. Ellis 
13 Suasa (Marche): metodologie di ricerca integrate per la ricostruzione storica della città 126 M. Destro and E. Giorgi

14 Nuove indagini integrate a Classe (Ravenna). Stato attuale e prospettive di ricerca F. Boschi

15 Ground Penetrating Radar Survey of Urban Sites in North Coastal Etruria: Pisae, Portus Pisanus, Vada Volaterrana.

M. Pasquinucci, S. Ducci, S. Menchelli, A. Ribolini, A. Bianchi, M. Bini and S. Sartini

16 The Ammaia Project: Integrated Approaches for Studying Roman Towns in Lusitania. C. Corsi

17 The Burnum Project: An Integrated Approach to the Study of a Roman Castrum in Croatia 170 F. Boschi and E. Giorgi

\section{PART 2: INTER-URBAN RELATIONSHIPS}

18 Urban Archaeology, Urban Networks and Population Dynamics in Roman Italy

L. de Ligt

19 GIS and Intervisibility Analyses for the Study Of Archaeological Landscapes - Problems of Interpretation. Case Study: The Murge Plateau in the Archaic Period

G. Semeraro

20 Surveying an Adriatic Valley: A Wide Area View on Early Urbanization Processes in Northern Picenum.

F. Vermeulen and D. Mlekuz

21 Setting Towns in their Landscape: Forms of Urbanism in the Ager Faliscus R. Opitz and S. Stoddart

\section{Concluding Notes}

22 Urban Landscape Surveys: A View from the End 232 N. Christie

23 A proposito di Urban Landscape Survey: qualche nota di método 236 F. Coarelli 


\section{Contributors}

P. Aтtema

Groningen Institute of Archaeology (GIA)

A. Bianchi
So.Ge.T., Lucca

M. Bini

Università di Pisa, Dpt. di Scienze della Terra

J. BinTLIFF

Leiden University, Department of Classical and

Mediterranean Archaeology

F. BoschI

Università di Bologna, Dipartimento di Archeologia

G.-J. Burgers

Koninklijk Nederlands Instituut Rome

D. Camardo

Herculaneum Conservation Project

G. Ceraudo

Università del Salento, Facoltà di Beni Culturali

N. Christie

University of Leicester

M. CIPRIANI

Soprintendenza per i Beni Archeologici delle Province di Salerno, Avellino, Benevento, Caserta - Museo Arch.

Naz. di Paestum

F. CoArelli

Universitá degli Studi di Perugia

C. Corsi

University of Cassino, Department of Humanities

M. Destro

Dipartimento di Archeologia, Alma Mater Studiorum

Università di Bologna

S. DuCCI

Soprintendenza per i Beni Archeologici della Toscana, Firenze

S. ELLIS

University of Cincinnati

E. Giorgi

Dipartimento di Archeologia, Alma Mater Studiorum Università di Bologna
S. GROH

Austrian Archaeological Institute, Vienna

T. DE HAAS

Groningen Institute of Archaeology (GIA)

S. HAY

APSS, University of Southampton

M. HeInZELmann

University of Cologne, Institute of Archaeology

D. JORDAN

University of Mainz, Institute of Geoscience

S. KAY

British School at Rome

S. KEAY

University of Southampton/British School at Rome

L. DE LigT

Leiden University

S. Menchelli

Università di Pisa, Dpt. Scienze Storiche del Mondo

Antico

F. Martens

Sagalassos Archaeologial Research Project, Katholieke Universiteit Leuven

M. Millett

University of Cambridge

D. Mlekuz

Ghent University, Department of Archaeology

B. MUŠıČ

Ljubljana University, Department of Archaeology

J. OGDen

L - P: Archaeology, Ltd.

R. OpITZ

University of Cambridge, Department of Archaeology

M. Pasquinucci

Università di Pisa, Dpt. Scienze Storiche del Mondo

Antico

J. Poblome

Sagalassos Archaeologial Research Project, Katholieke Universiteit Leuven 
A. RibOLINI

Università di Pisa, Dpt. di Scienze della Terra

A. SANTORIEllo

Dipartimento di Beni Culturali, Università di Salerno

S. SARTINI

So.Ge.T., Lucca

G. SCARDOZZI

CNR-IBAM, Consiglio Nazionale delle Ricerche -

Istituto per i Beni Archeologici e Monumentali, Lecce

G. Semeraro

University of Bari

B. SLAPŠAK

University of Ljubljana
S. STODDART

University of Cambridge, Department of Archaeology

K. STRUTT

APSS, University of Southampton

G. TUCKER

British School at Rome

F. VermeUlen

Ghent University, Department of Archaeology

M. WAELKENS

Sagalassos Archaeological Research Project, Katholieke Universiteit Leuven 


\title{
The Integrated Urban Survey at Sagalassos
}

\author{
F. Martens, B. Mušič, J. Poblome and M. Waelkens
}

\section{Introduction}

Sagalassos is located c. $110 \mathrm{~km}$ north of Antalya. Since 1990 the town and its territory $\left(c .1200 \mathrm{~km}^{2}\right)$ have been investigated as part of an interdisciplinary research project of the Katholieke Universiteit Leuven (Belgium) directed by M. Waelkens (Waelkens 2004; 2006). After a first decade of large-scale excavations mainly within the monumental centre, an integrated research strategy was devised and applied to obtain a better insight into the development of the town plan (Figure 9.1) and the chronological evolution and functional organization of the urban area. This research comprised a programme of test soundings on the network of streets (1998-2008: Martens 2007; 2008) and an architectural and intensive surface survey covering over two-thirds (23.43ha) (Figure 9.2) of the inhabited urban area (c. 31.5ha) within the sepulchral zones (1999-2005: Martens 2005; Martens et al. 2008). The results of this work could be combined with the evidence generated by other non-invasive techniques including geophysical survey (since 2002), supervised by Branko Mušič (2008; Mušič et al. 2009).

\section{State of the art}

For a long time archaeological survey in Turkey was largely confined to single-period or architectural-epigraphic survey projects (Alcock 1994: 181). This situation has been changing fast during the last decade (Y1ldirım and Gates 2007: 277), as is also testified by the growing number of survey projects represented in the yearly conference proceedings of non-invasive archaeological research in Turkey (Araştırma Sonuçları Toplantısı). Although the number of multi-method urban surveys still remains limited, ongoing projects on major sites (Ephesos: Groh et al. 2006: 48, n. 10; Troia: Jablonka
2006: 6-7) are conducting intensive surface collections, combined with geophysical survey. In addition, site based topographical/architectural surveys are increasingly incorporating these survey techniques as well, as in the case of the 'Pisidia Project' (e.g. Vandeput and Köse 2004; Vandeput et al. 2005). Modern research at Sagalassos was initiated within the framework of the 'Pisidia Project' (1985-1989: Mitchell 1998, with references; Waelkens 2006: 325-326). Meanwhile, large-scale excavations and the interdisciplinary investigation of town and territory (Waelkens 2008) have made Sagalassos one of the better documented sites of Pisidia. The urban research allowed reconstructing the building history of Sagalassos from the Hellenistic period ${ }^{1}$ into the seventh century AD, whereby a devastating earthquake, occurring between 600 and 620AD (De Cupere et al. 2009), further enhanced the decline, which had already set in during the second half of the sixth century AD.

As opposed to earlier assumptions, however, the site continued to be inhabited by small-scale communities at least into the thirteenth century AD (Vionis et al. 2009: 193). For the town's chora the occupation pattern was first explored with a reconnaissance survey (1993-1998) (Vanhaverbeke and Waelkens 2003), forming the basis for an intensive survey (1999-2006) by H. Vanhaverbeke applying a stratified sampling strategy in the primary catchment area of the settlement within a $c .5 \mathrm{~km}$ radius (one hour walking from the town across flat terrain) (Vanhaverbeke in Martens et al. 2008). Simultaneously with the hinterland survey, in 1999 also the urban survey was initiated. As there was no comparable work in Turkey at this time, the initial research design followed the example of the Boeotia survey (Bintliff and Snodgrass 1985). However, the unploughed character of Sagalassos, the low finds density and the steeply sloping terrain conditions presented major methodological challenges. 


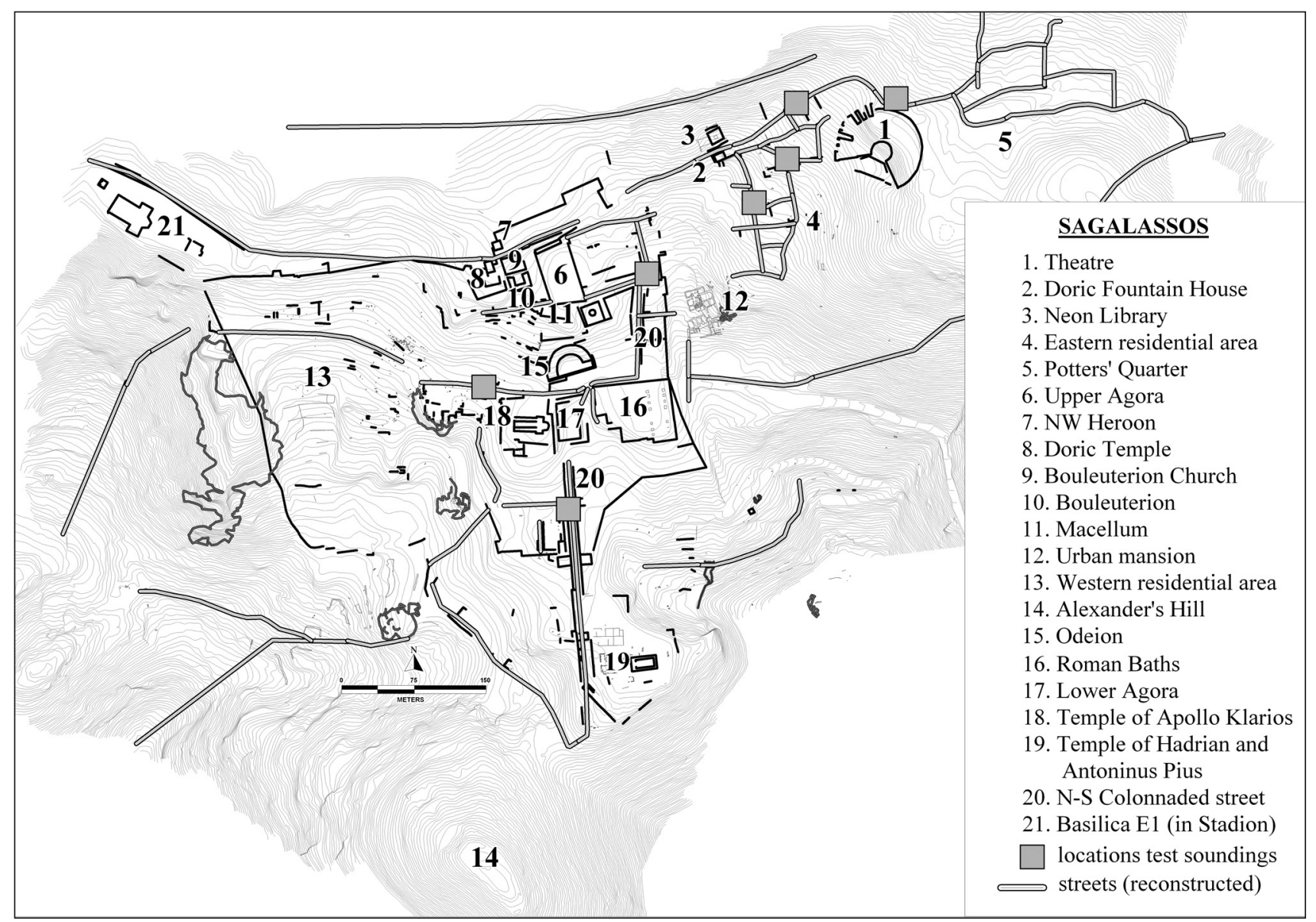

Figure 9.1 The urban plan of Sagalassos with the street system as reconstructed on the basis of excavations and geophysical survey (F. Martens; B. Mušič).

For the application at Sagalassos of high resolution shallow geophysics, the challenges were posed by the diverse archaeological contexts of different origin and preservation, the alternating geomorphological units with natural or man-made obstacles at the surface and the diverse top soil compositions of varying depths and lithologically variable underlying bedrock. As it was difficult to classify the signal to noise ratio for each geophysical technique for such diverse or unpredictable subsurface conditions, a multi-method approach was designed using various complementary geophysical methods, as tested at Tanagra (Boeotia) (Bintliff et al. 2000; 2001; Mušič et al. 2004; 2005) or Trea (Potenza Valley) (Vermeulen et al. 2009: 85-110). In addition, the approach of other surveys in comparable conditions was consulted to resolve specific tasks and special attention was paid to certain algorithms used in the processing flow for enhancing the signal to noise ratio.

\section{Methodology}

\section{The intensive archaeological survey}

Field conditions at Sagalassos differed from many other archaeologically surveyed Mediterranean sites in the sense that the town was laid out on sloping terrain, which had not been intensively cultivated after the end of the large-scale occupation. This had consequences for the distribution of the surface material. The absence of a regular turnover of artefacts in the soil implied that a chronological superposition of archaeological evidence was to be expected, whereby the last phase of the large-scale occupation prevailed in the surface record (Figure 9.2), unless when disturbed by post-depositional processes. This situation, together with the fact that the average pottery densities proved to be rather low $\left(0.2\right.$ sherds per $\left.\mathrm{m}^{2}\right)$ with a small amount of diagnostic sherds $\left(0.03 \text { per } \mathrm{m}^{2}\right)^{2}$ especially in comparison to the rates seen in many Mediterranean surveys, urged us to try and control or assess as much as possible the impact of biases 


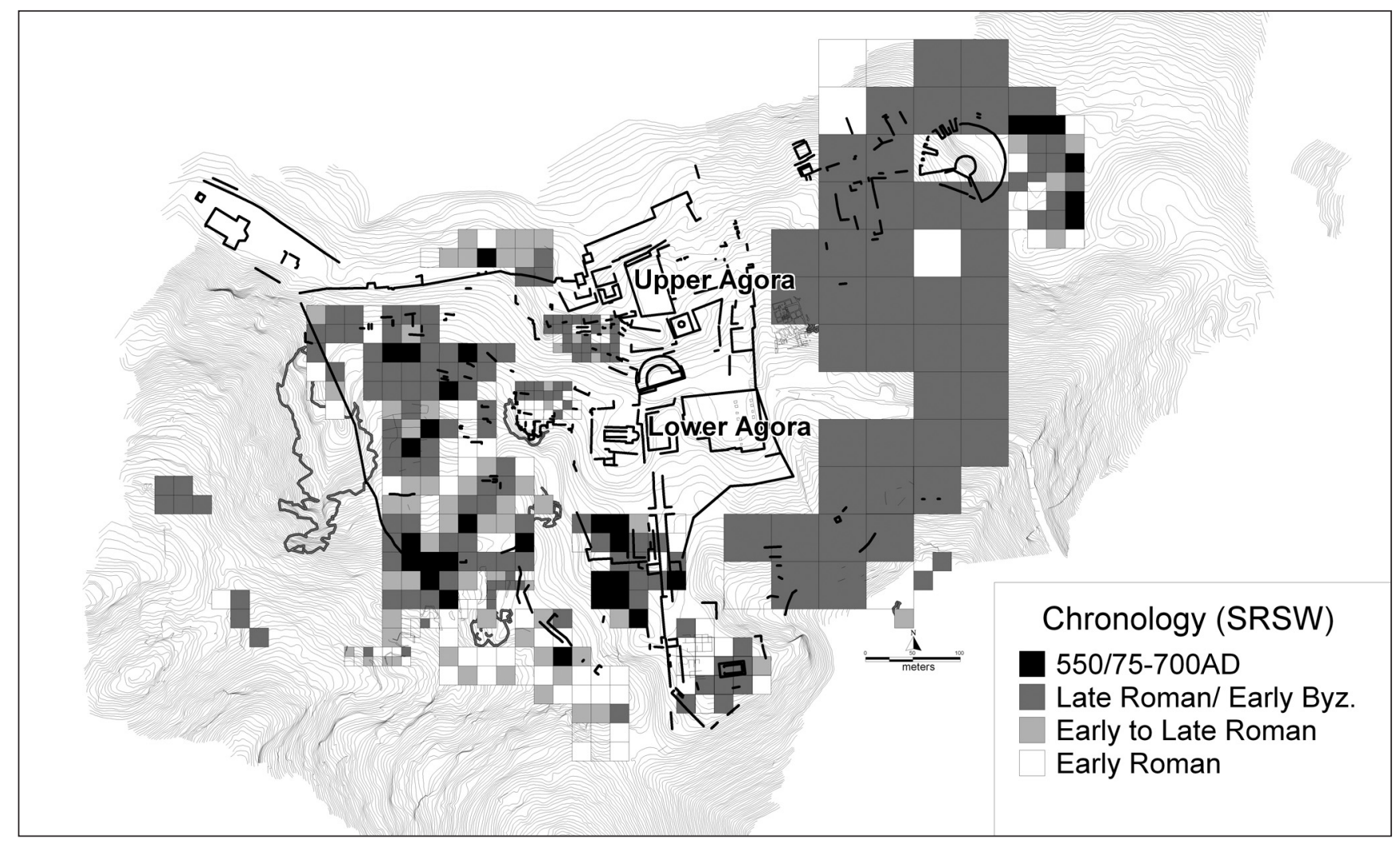

Figure 9.2 The chronological distribution of the surface finds, showing the youngest prevalent period per surveyed square (F. Martens).

either related to the survey procedure or caused by the field conditions (Martens et al. 2008).

Firstly, with regard to the field strategy, the intensity of the coverage, the size of the grids and the choice of the collected material were important. The field strategy evolved from a sampling strategy (1999) based on $50 \times 50 \mathrm{~m}$ squares, providing a reliable yet insufficiently differentiated research result, over a too intensive and thus slowly progressing full coverage strategy in grids of $10 \times 10 \mathrm{~m}(2000)$, to result in an intensive coverage of squares of $20 \times 20 \mathrm{~m}$ with a walker distance of $2 \mathrm{~m}$, which ultimately proved to be both timeefficient and most likely to produce a representative data-set (Martens 2005: 235-240: figs 3, 5).

To calibrate the density counts and to compensate for the level of ground cover the degree of surface visibility was assessed using five classes with increasing visibility. Objections have been formulated against using visibility rates to produce visibility corrected pottery distribution maps (Lock et al. 1999: 59-60; Meyer and Schon 2003: 52-57; Thompson 2004). One of the arguments is that the empirical data of the density count are multiplied with a factor generated on the basis of a subjective visibility allocation (Mattingly 2000: 12). Yet, provided that the raw data are presented as well and that 'corrected figures' are marked as such, visibility correction can be justified. By using five instead of ten classes (as in the Boeotia survey), the visibility categories could be linked to clearly described field conditions (involving specific constellations and vegetation species) which were thus more likely to be assessed in the same manner by all field walkers. To increase the reliability of the surface collection all material - diagnostic as well as non-diagnostic - was counted and collected, except for building ceramics which were counted in the field. Surface architecture was measured and mapped on a scale 1:200. Two teams of five persons surveyed simultaneously and to improve the consistency of the procedure meters were laid out along each grid. As such the person registering the density counts and visibility assessments could ensure that equal ranges were covered per step. Prior to the survey, team members were introduced to the material at the project's find depots and in the field it was checked regularly whether they used the same standards for density counts and visibility assessments.

A second and even more important bias for the surface survey comprised site formation processes and postdepositional disturbance. The monumental centre of Sagalassos was laid out on a complex of extended limestone platforms, whereby the homogeneous debris slope with grasses and low shrubs of the Eastern Residential Area contrasted strongly with the terraced western domestic (Martens 2005: 234, fig. 4), artisanal and sepulchral zones 
with more rugged vegetation. Geomorphological research suggested that these sloping terrain features combined with other physical agents (local absence of vegetation, heavy rainfall causing surface run off, animal trampling) exposed the archaeological record to significant post-depositional disturbance (Paulissen et al. 1993; Martens et al. 2008: 131, with further references). This was exemplified by a comparison of the surface-subsurface conditions. In the Eastern Residential Area, surveyed with the 1999 sampling strategy, test soundings 'TSW1' and 'TSW2' were excavated (Figure 9.1: 4; Martens 2007: 324, fig. 2: 7). In these trenches either through man-induced or natural erosive processes - possibly after the decay of certain retaining structures - exclusively early Imperial contexts were excavated, which were not represented in the surface record here, where as an overall result the late antique period prevailed (Martens et al. 2008: 132). At the western edge of the same residential zone also trench 'TSW5' testified severe (local?) surface erosion (Martens 2007: 324, fig. 2: 11; 352-353). Elsewhere in the Eastern Residential Area the chronology of the excavated levels did reappear in the surface material, but not necessarily in a quantitatively proportional relationship. ${ }^{3}$ The 1999 sampling strategy, in general, proved to be less well suited to record ill-represented periods or non-ceramic material categories. As opposed to the eastern part of the site, early to middle Imperial sherds did appear in high densities ('chronological windows') in the western part of the site, especially at those locations where severe erosive processes affected sparsely vegetated slopes (Martens 2005: 246-248; Martens et al. 2008: 136-137).

\section{The geophysical survey \\ (B. Mušič)}

As for surface collection, also for geophysics there is no 'cook-book strategy'. In compliance with the field conditions of each zone, various geophysical techniques were applied at Sagalassos, building upon preceding results and with feedback offered by evidence from the excavations. Initially a testing polygon (c. 1ha) was selected within the Eastern Residential Area, whereby the reliability of the results could be verified using the data from the test soundings (Martens 2007). In the period 2002-2010, an area of over 12ha was surveyed at the eastern half of the site using the magnetic method, of which 37 regions (c. 3.6ha) were re-surveyed by closely spaced parallel GPR profiles (Figure 9.3). The

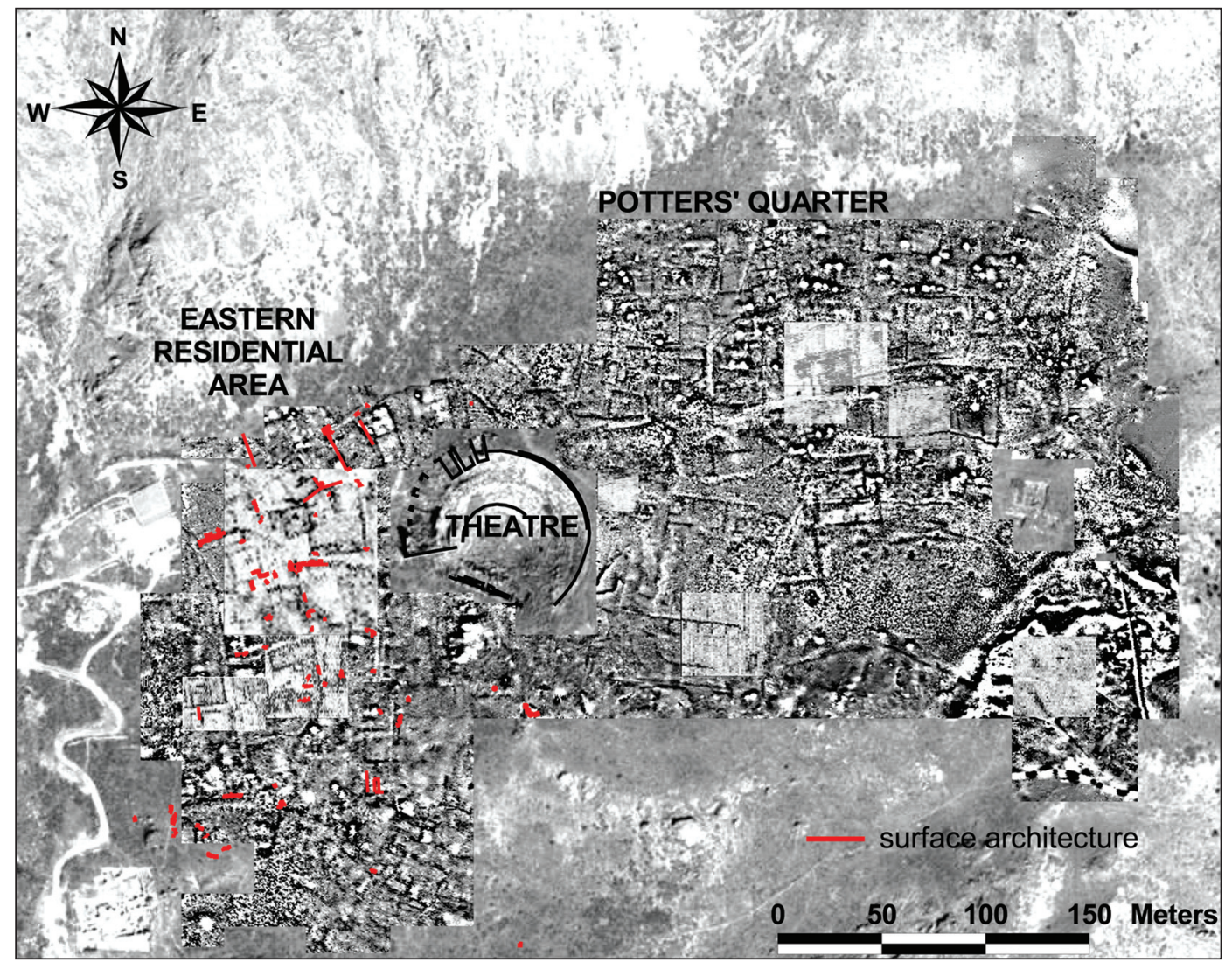

Figure 9.3 Selected GPR time slices and mapped surface architecture on the magnetometry map of the Eastern Residential Area and Potters' Quarter (B. Mušič; F. Martens) (Satellite image: (C) 2003: Digital Globe. All rights reserved. 19.09.2003 at 8.30 AM). 
resistivity and conductivity methods were applied to a lesser extent at the Eastern Residential Area and Potters' Quarter. These procedures will be outlined below.

In the earliest stages, the field work comprised a magnetic survey measuring the vertical gradient of the earth's magnetic field by means of a Fluxgate gradiometer Geoscan FM36 in addition to resistivity mapping with a resistance meter Geoscan RM15 in a twin probes configuration. Considering the rough terrain conditions, the choice of a light-weight easily portable magnetometer was self-evident. The measurements in grids of $0.5 \times 0.5 \mathrm{~m}$, however, were not entirely satisfactory due to the lower resolution of the fluxgate sensors in comparison to the optically pumped caesium sensors. Moreover, for the resistivity mapping the high-resistivity contact was hindered by the surface debris and the dryness of the topsoil. 2D resistivity sections across the Eastern Residential Area (Similox-Tohon et al. 2004: 1-18), however, suggested the presence of well-preserved archaeological structures $(c .2 .5 \times 5 \mathrm{~m})$ (see also Mušič et al. 2009).

Consequently, a total field magnetometer Geometrics G-858 in gradient mode was introduced, which generally amplifies the weak magnetic anomalies of small structures at shallow depths in favour of long-wave anomalies caused by the geological background. This magnetometer also allowed observing magnetic field readings separately on the top and the bottom sensors, so that a single sensor resolution approach, a more refined method for specific archaeological contexts (e.g. potters' workshops), could be tested (Tabbagh 2003: 75-81; Mušič 2008: 60: fig. 13). The Geometrics G-858 attained a resolution of $0.1-0.2$ $\mathrm{nT} / \mathrm{m}$ in measuring the total magnetic field density with an acquisition at a rate of $5 \mathrm{~Hz}$ along the $0.5 \mathrm{~m}$ spaced transects. The readings were interpolated to a sample interval of $0.25 \mathrm{~m}$ using the cubic 'spline approximation to the sinc function'.

The magnetic method especially produced excellent results for the northeastern part of the town. Measurements of the apparent magnetic susceptibility of samples of top soil, excavated levels or drillings revealed extremely high susceptibility values at the Eastern Residential Area and Potters' Quarter (see Mušič 2008, 54: fig. 3). Aside of the thermoremanent magnetization, also the significant differences between the susceptibility of the (limestone) building materials and the surrounding soil, ${ }^{4}$ induced a clear representation of the archaeological remains (Figure 9.3). Besides of the anthropogenic agents, the observed differences in magnetic susceptibility of the topsoil were also determined by the complex geology of the site (see Similox-Tohon et al. 2004: 1-18). The magnetic method picked up the induced magnetization typical for stone built walls (in the Eastern Residential Area) and the strong thermoremanent magnetization of clay-built structures (e.g. kilns in the Potters' Quarter).
In the data processing some less common approaches were used to amplify the signal-to-noise ratio. Due to the bipolar nature of the geomagnetic field, magnetic anomalies located elsewhere than at the magnetic poles are asymmetric even when the magnetic source distribution is symmetrical. In general, the RTP transformation (see Telford et al. 1990) significantly reduces the complexity of the distinctive bipolarity of induced and thermoremanent magnetic anomalies, which is characteristic for the latitude of Sagalassos. As such, e.g. walls detected close to each other could still be accurately discerned (Mušič 2008: 55, fig. 4; 57, fig. 8). The Sagalassos results demonstrated that this transformation was also useful for objects with thermoremanent magnetization (kilns; furnaces; forges) (Mušič in Uytterhoeven et al. 2010: 303, fig. 3).

For interpreting the results all-encompassing 2D archaeophysical magnetic models were convenient (e.g.: Mušič and Orengo 1998: 157-186, Mušič and Horvat 2007: 219-283, Mušič 2008: 58, fig. 10), which were generated by comparing on-site measured values of the total magnetic field density with the calculated magnetic anomalies for the presumed archaeo-physical model. Such model's variables comprise the shape, dimensions and depth of the presumed remains and the magnetic susceptibility values of the building material.

Finally, a better recognition of anomalies was obtained by determining the deeper magnetic sources with a significant background noise reduction using the upward continuation (Mušič 2008: 57, fig. 7). The values of the potential earth's magnetic field can be calculated using measurements of the magnetic field at a certain level above the modern surface. Residual magnetic anomalies are obtained by subtracting the upward continuation field from the initial on-field observation. The residual magnetic field is opposed to the upward continuation, which is normally used for the recognition of high frequency magnetic disturbances from sources close to the surface (Yaoguo and Oldenburg 1998: 431-439). At Sagalassos higher residuals corresponded to areas diffusely polluted by strongly magnetic iron minerals (blacksmiths' and/or potters' activities?) (Mušič 2008: 58, fig. 9).

In a later stage of the geophysical survey at Sagalassos Ground Penetrating Radar (GPR) sounding was introduced. This technique, using 200, 400 and $500 \mathrm{MHz}$ antennas (GSSI SIR3000), was applied on the instigation of the magnetometry results to resolve research questions concerning the reconstruction of the water network (preservation issues) and the street system (presence or absence of pavement) or the analysis of complex building remains. The quantitative data required for a $3 \mathrm{D}$ display of the architectural remains was obtained through an analysis of individual GPR echoes. While the width of the walls was deduced by applying migrations and Hilbert's transformations, the preserved depths were determined using the 'hyperbola adaptation method' (Conyers 
and Lucius 1996: 25-38). However, the propagation velocity of the electromagnetic waves altered throughout the site due to the subsurface composition and soil moisture.

The GPR results confirmed the suitability of the more robust $200 \mathrm{MHz}$ antenna, rather than the $400 \mathrm{MHz}$ antenna, which was better-suited for surveying shallow archaeological targets. The upper and lower limits of a horizontal reflector (e.g. a paved street surface), was visible on the radargram if its width exceeded one quarter of the wavelength. At the estimated dielectric permittivity (10-12) of the soil of the northeastern part of the town the wavelength of the $200 \mathrm{MHz}$ antenna measured c. $0.5 \mathrm{~m}$, implying that horizontal layers (paved areas) thicker than $0.1 \mathrm{~m}$ were reliably discerned on the radargrams. For representing the GPR results the 'time slices method' was used showing a series of parallel, usually equally spaced profiles (Figure 9.3) (e.g. Goodman et al. 1995, Mušič in Uytterhoeven et al. 2010: 304, fig. 4), in addition to 3D visualizations (Mušič 2008: 61, fig. 15; Mušič in Uytterhoeven et al. 2010: 304, fig. 5).

Based on the results of the magnetic prospection at Sagalassos, as a last technique, the electric conductivity method using electromagnetic induction (Geonics EM38) was tested. Measurements were carried out in 'step mode' with a $0.5 \mathrm{~m}$ interval using the instrument's highest sensitivity (depth: $1 \mathrm{~m}$ ). As anticipated in these extremely dry soil conditions the results were somewhat better in areas with quick lateral changes in the top soil susceptibility, but generally this method was less suited for Sagalassos.

\section{Results}

The integrated research strategy applied at Sagalassos contributed to various research questions concerning the organization and chronological development of the urban area (for a detailed overview see Martens 2005: 242-249, figs. 7, 11, 12; Martens et al. 2008: 135-139; Martens in prep.). As a general chronological result, the large-scale occupation of the urban area, which based on the excavated evidence seems to have experienced a swift expansion beyond the Hellenistic wall circuit from early Imperial times onwards, proved to have continued into the sixth century AD (Figure 9.2), with a less extensive (and less dense?) occupation during the later sixth and into the seventh century AD.

A re-study (2007-2009) of all of the collected pottery including also the non-diagnostic sherds ${ }^{5}$, allowed identifying scatters of formerly ill-known Classical/Hellenistic and early medieval to mid Byzantine sherds throughout the urban area, thus filling in gaps in the settlement history of Sagalassos and offering better grounds to study the significance of the town within the region during these periods. Remarkably high densities of Classical/Hellenistic pottery on the erosive slopes in the artisanal-sepulchral zone southwest of the walled circuit refer to an active exploration of this area during this period, the nature of which remains to be further investigated.

At the other end of the chronological balance, surface pottery from the promontory of the former sanctuary of Hadrian and Antoninus Pius (Figure 9.1: 19) proved to correspond with the occupation of this fortified refuge from the later seventh-eighth century onwards and in middle Byzantine times, as was revealed by excavations here (Vionis et al. 2009: 192, 200).

With regard to the spatial organization of the town the analyses of find categories other than pottery (including surface architecture), combined with the results of geophysics and test soundings, allowed determining a basic functional zoning, whereby the monumental centre proved to be flanked to the east and west by residential zones including a variety of urban functions (see Martens 2005: 242-245; Martens in Uytterhoeven et al. 2010). Artisanal zones were excluded from these domestic areas and concentrated in the southwestern and eastern periphery of the site, close to or intermingled with the sepulchral zones surrounding the town. Whereas in the area of the Potters' Quarter, which was not covered by the archaeological survey, kilns and workshop infrastructure could be identified through geophysics (Figure 9.4; Mušič et al. 2009: fig. 9, 10, 13) and excavations (Murphy and Poblome 2011), in the southwestern artisanal zone metal working was identified through geochemical analyses (Kellens et al. 2003: 551-552). ${ }^{6}$

As for the urban planning of Sagalassos, on these steep terrain conditions a technologically sound principle of practical planning proved to be applied. In the Eastern Residential Area e.g., groups of insulae - which from early Imperial times onward were supplied with running water - were divided by $2-3.50 \mathrm{~m}$ wide streets (Figures $9.4,9.5$ ), which were only partly accessible to wheeled traffic. These insulae showed different orientations, either following the cardinal directions or determined by the direction of the slope. After a major phase of urban layout during the first half of the first century AD at least one major building phase followed during the second-third century $\mathrm{AD}$, whereas certain plots were no longer in use in late antique times (Martens 2008; for a detailed description, see Martens in Uytterhoeven et al. 2010, 289-307). Particular methodological challenges for geophysics concerning the possibility to distinguish paved street surfaces from dismantled streets or to identify and trace well-preserved stone or brick-built water channels, remained problematic unless reference could be made to nearby excavations. 


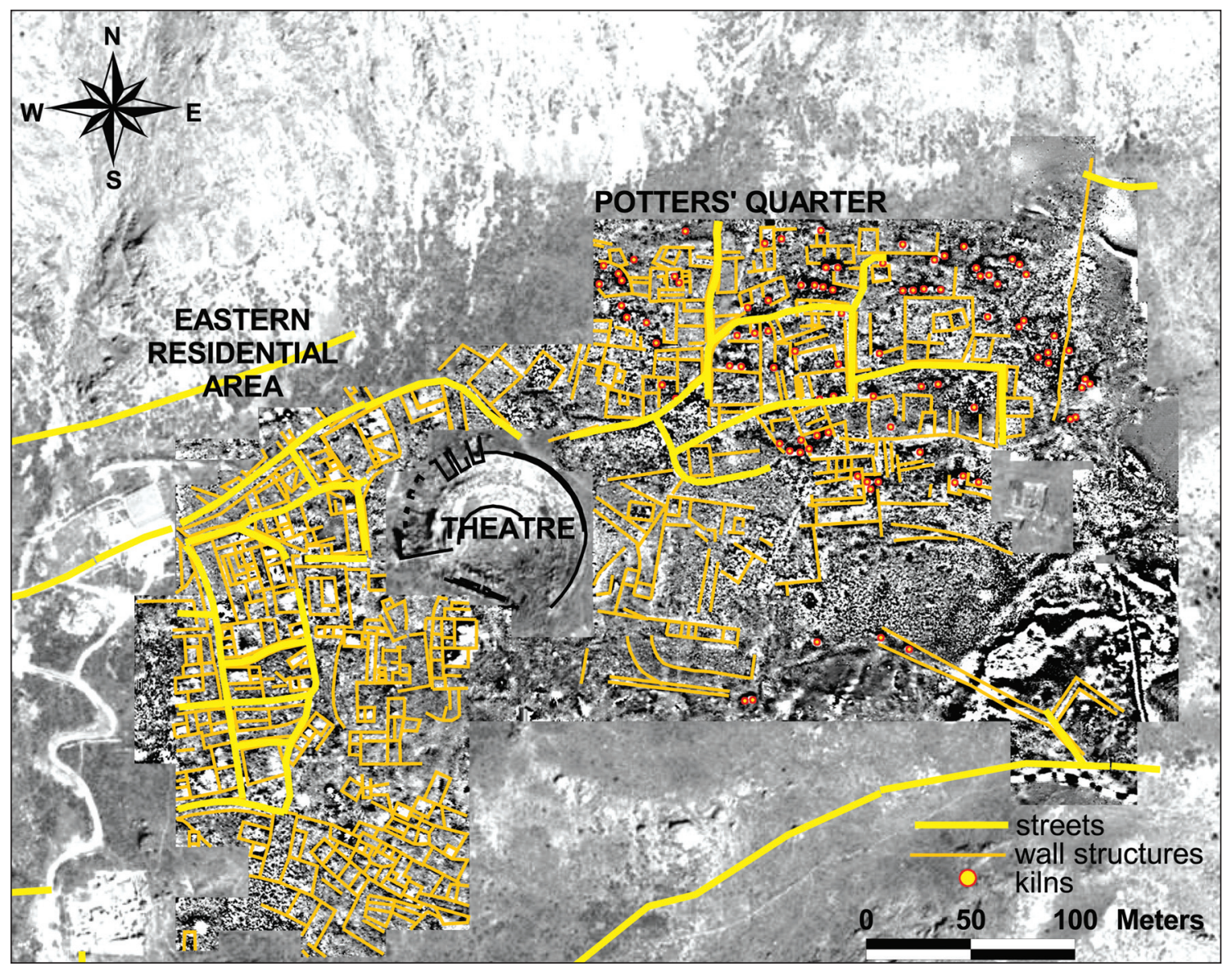

Figure 9.4 Interpretation of the results of geophysics at the Eastern Residential Area and Potters' Quarter (B. Mušič) (Satellite image: (C) 2003: Digital Globe. All rights reserved. 19.09.2003 at 8.30 AM).

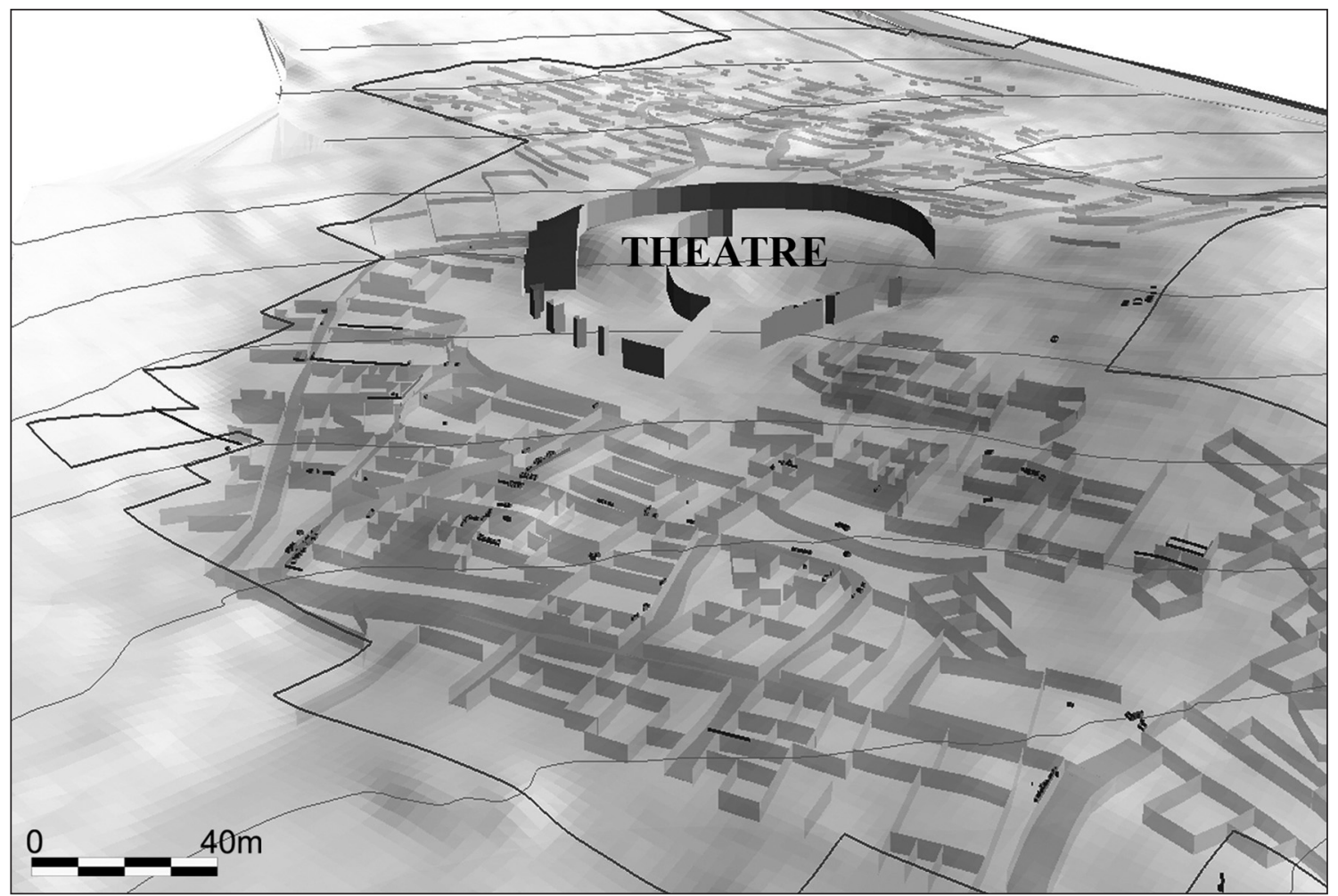

Figure $9.53 D$ view of the north-eastern part of Sagalassos from the southwest, demonstrating the integral interpretation of the results of the multi-method geophysical approach (B. Mušič). 


\section{Conclusions}

This paper illustrated how, both for the archaeological as well as for the geophysical survey, devising an appropriate site-specific strategy was a process of trial-and-error. A number of issues could be remedied by an improved research design or had to be born in mind as a restriction for the interpretation of the research results. For the archaeological survey the diversified terrain conditions with a differential impact of post-depositional processes implied that a more intensive survey strategy had to be applied to increase the reliability of the results. The fact that all surface finds were collected allowed a re-study of the sherds, as pottery research evolved. For the investigation of the historical evolution of the urban area the chronological superposition of pottery on the uncultivated terrain nevertheless implied that the absolute number of sherds could not be used to simply measure changes in site size or occupation intensity.

In addition to a clear insight into the functional zoning of the urban area, the archaeological survey thus offered a spatial view on general chronological trends for which the outlines had been offered by the results of epigraphical research, architectural studies and excavations in the monumental centre. For the particular situation of Sagalassos, the collected surface evidence on its own would not have been unequivocal enough to offer these insights independently. By combining the survey results with other research data (surface architecture, results from geophysical survey, test-soundings, large-scale excavations) the quality and restrictions of the surface evidence could be better assessed, while obviously the reliability of the obtained overall picture increased significantly by this integrated approach targeting the entire urban area.

\section{Acknowledgements}

This research was supported by the Belgian Programme on Interuniversity Poles of Attraction (IAP 6/22) and the Research Fund of the K.U.Leuven (BOF-GOA 07/02), in addition to projects G.0421.06 and G.0788.09 of the Research Council-Flanders (FWO). M. Waelkens is beneficiary of a Methusalem Grant of the Flemish govenment.

\section{Notes}

1 The relationship between Sagalassos and the in 2005 discovered Classical/Hellenistic site at 'Düzen Tepe' $1.8 \mathrm{~km}$ southwest of Sagalassos, occupied from the $c$. fifth until the second century BC, is still under investigation (Vanhaverbeke et al. 2010, Waelkens et al. submitted).

2 These averages are calculated on the basis of the pottery evidence from 238 grids of $20 \mathrm{~m}^{2}$ (2001-2005).

3 The relationship between evidence from survey and excavations is further discussed in Martens in prep.
4 For instance, the mean top soil susceptibility values for the Eastern Residential Area $\left(4.53 \times 10^{-3} \mathrm{SI}\right)$ and northern and western parts of the Potters' Quarter $\left(5.48 \times 10^{-3} \mathrm{SI}\right)$ are comparable. Extremely high top soil susceptibility results mainly from the large quantities of pottery dust mixed in the top soil. The mean susceptibility value of kilns excavated at the Potters' Quarter in 2004 is $19.86 \times 10^{-3} \mathrm{SI}$. The lower average susceptibility at the eastern part of Potters' Quarter $\left(2.75 \times 10^{-3} \mathrm{SI}\right)$ refers to the lower top soil susceptibilities upon the ophiolitic melange.

5 Whereas the initial analyses were based solely on diagnostic table wares (Sagalassos Red Slip Ware), the new approach developed by J. Poblome and applied by the pottery team (N. Firat and others) included all sherds, taking into account various functional categories and full typological date ranges (for a first approach, see Poblome et al. in Bintliff et al. 2004: 561-569). Upon this new dataset various data distribution techniques were applied by $\mathrm{R}$. Willet. The results offer a better view on the representation of various chronological periods, but the functional analysis of the pottery now also allows an assessement of the composition or quality of the 'assemblages'. Hereby, a general preponderance of pottery types used for consumption and serving as opposed to a minority of cooking and other wares (transport, storage, preparation) was noticed for the early and middle Imperial periods, whereas only the late antique material seemed to comprise viable functional (domestic) 'surface assemblages'. These issues, whether influenced by terrain conditions, the impact of the local potters' industry (SRSW) or other contributing factors, are now further investigated in collaboration with J. Poblome and R. Willet (Martens in prep.).

6 Waste products of local metal working or pottery production were commonly used respectively for road metalling or construction activities (levelling, terracing). Geochemical analyses of soil samples from areas with concentrations of metal slag allow a more secure functional interpretation. For references on the research on pottery production, metal working and secondary glass working at Sagalassos, see Waelkens 2008: 10-11.

\section{References}

Alcock, S. E. (1994) Breaking up the Hellenistic world: survey and society. In I. Morris (ed.), Classical Greece. Ancient Histories and Modern Archaeologies: 171-190. Cambridge: Cambridge University Press.

Bintliff, J. L. and Snodgrass, A. M. (1985) The Cambridge/ Bradford Boeotian Expedition: The First Four Years. Journal of Field Archaeology 12: 123-161.

Bintliff, J. L., Farinetti, E., Sbonias, K., Sigalos, L., Slapšak, B. and Mušič, B. (2000) The Tanagra survey. Report on the 2000 season. Pharos 8: 93-128.

Bintliff, J. L., Evelpidou, N., Farinetti, E., Mušič, B. and Slapšak, B. (2001) The Tanagra survey. Report on the 2001 season. Pharos 9: 33-74.

Bintliff, J., Farinetti, E., Sbonias, K., Poblome, J., Sarri, K., Vionis, A., Mušič, B. and Slapšak, B. (2004) The Tanagra project: Investigations at an ancient Boeotian city and in its countryside (2000-2002). Bulletin de Correspondance Hellénique 128: 541-606. 
Conyers, L. B. and Lucius, J. E. (1996) Velocity analysis in archaeological ground-penetrating radar studies. Archaeological Prospection 3: 25-38.

De Cupere, B., Thijs, S., Van Neer, W., Ervynck, A., Corremans, M. and Waelkens, M. (2009) Eagle owl (Bubo bubo) pellets from Roman Sagalassos (SW Turkey): Distinguishing the Prey Remains from Nest and Roost Sites. International Journal of Osteoarchaeology 19: 1-22.

Goodman D., Nishimura, Y. and Rogers, J. D. (1995) GPR time slices in archaeological prospection. Archaeological Prospection 2: 85-89.

Groh, S. with Lindinger V., Löcker, K., Neubauer, W. and Sirri Seren, S. (2006) Neue Forschungen zur Stadtplanung in Ephesos. (Jahreshefte des Österreichischen Archäologischen Institutes in Wien. Sonderdruck 75) : 47-116. Wien: Österreichischen Akademie der Wissenschaften.

Jablonka, P. (2006) Vorbericht zu den Arbeiten in Troia 2005Preliminary report on work at Troia in 2005, Studia Troica 16: 3-26.

Kellens, N., Degryse, P., Martens, F. and Waelkens, M. (2003) Iron production activities and products at Roman to early Byzantine Sagalassos (SW Turkey). In Archaeometallurgy in Europe. International Conference, 24-26 September 2003, Milan, Vol. 1: 545-554. Milan: Associazione Italiana di Metallurgia.

Lock, G., Bell, T. and Lloyd, J. (1999) Towards a Methodology for Modelling Surface Survey Data: The Sangro Valley Project. In M. Gillings, D. Mattingly and J. van Dalen (eds), Geographical Information Systems and Landscape Archaeology (The Archaeology of Mediterranean Landscapes 3): 55-63. Oxford: Oxbow Books.

Martens, F. (2005) The archaeological urban survey of Sagalassos (SW Turkey): The possibilities and limitations of surveying a 'non-typical' classical site. Oxford Journal of Archaeology 24(3): 229-254.

Martens, F. (2007) Late antique urban streets at Sagalassos. In L. Lavan, E. Zanini and A. Sarantis (eds), Technology in Transition. A.D. 300-650 (Late Antique Archaeology 4(1)): 321-365. Leiden: Brill.

Martens, F. (2008) Urban traffic in the hills of the Eastern Mediterranean: The development, maintenance, and usage of the street system at Sagalassos in South-Western Turkey. In P. Ballet, N. Dieudonné-Glad and C. Saliou (eds), La rue dans l'antiquité: Definition, amenagement et devenir, Actes du colloque de Poitiers, 7-9 Septembre 2006: 191-200. Rennes: Presses Universitaires de Rennes.

Martens, F. (in preparation) The Urban Development of Sagalassos. Town Planning and settlement Evolution (Studies in Eastern Mediterranean Archaeology 9). Turnhout: Brepols.

Martens, F., Vanhaverbeke, H. and Waelkens, M. (2008) Town and suburbium of Sagalassos: an interaction investigated through survey. In H. Vanhaverbeke, J. Poblome, M. Waelkens, F. Vermeulen and R. Brulet (eds), Thinking about Space. The Potential of Surface Survey and Contextual Analysis in the Analysis of Space in Roman Times (Studies in Eastern Mediterranean Archaeology VIII): 127-149. Turnhout: Brepols.

Mattingly, D. (2000) Methods of collection, recording and quantification. In R. Francovich, H. Patterson and G. Barker (eds), Extracting Meaning from Ploughsoil Assemblages (The Archaeology of Mediterranean Landscapes 5): 5-15. Oxford: Oxbow Books.

Meyer, N. and Schon, R. (2003) Experimental data. In M. Given and A. B. Knapp, The Sydney Cyprus Survey Project. Social Approaches to Regional Archaeological Survey (Monumenta Archaeologica 21): 52-56. Los Angeles: Cotsen Institute of Archaeology.

Mitchell, S. (1998) The Pisidian Survey. In R. Matthews (ed.), Ancient Anatolia. Fifty years'work by the British Institute of Archaeology at Ankara: 237-253. London: British Institute of Archaeology.

Murphy, E. and Poblome, J. (2011) Producing pottery vs. producing models: interpreting workshop organization at the Potters' Quater of Sagalassos. In M. L. Lawall and J. Lund (eds), Pottery in the Archaeological Record: A view from the Greek World (Gösta Enbom Monograph Series 1): 29-36. Copenhagen: Aarhus Universitets Forlag.

Mušič, B. (2008) Nastavki za kvantitativno analizo rezultatov arheološke geofizike na primeru Sagalassosa, Turčija = Starting points for a quantitative analysis of archaeological geophysics results on the example of Sagalassos, Turkey. Arheo (Ljublj.) 25: 53-67.

Mušič, B. and Horvat, J. (2007) Nauportus - an Early Roman trading post at Dolge njive in Vrhnika: the results of geophysical prospecting using a variety of independent methods. Arheološki vestnik 58: 219-283.

Mušič, B. and Orengo, L. (1998) Magnetic investigation of the Iron Age iron-smelting complex at the Cvinger near Meniška vas. Arheološki Vestnik 49: 157-186.

Mušič, B., Slapšak, B. and Farineti, E. (2004) Ancient Tanagra (Grimadha): Geophysical prospection and modelling for understanding of urban plan and on-site activity areas. In K. Fischer Ausserer (ed.), [Enter the past]: the e-way into the four dimensions of cultural heritage. Proceedings of the 30th CAA Conference, Vienna, April 2003 (BAR International Series 1227): 317-320. Oxford: Archaeopress.

Mušič, B., Farinetti, E., Kramberger, D. and Slapšak, B. (2005) The Tanagra project: investigations at an ancient city and its countryside (2000-2002): Geophysical and architectural survey. Bulletin de Correspondence Hellénique. Études et rapports 128-129: 579-606.

Mušič, B., De Laet, V., Martens, F., Similox-Tohon, D., Verstraeten, G., Poblome J., Talloen, P., Uytterhoeven, I. and Waelkens, M. (2009) Geophysics, satelite imagery, urban survey and archaeological excavations - complementary contributions to reconstruct a past urban landscape - the case of Sagalassos (SW-Turkey). In W. Börner (ed.), Archäologie und Computer, 5.-7. November 2008, Workshop 13: Kulturelles Erbe und neue Technologien: 1-23.Wien: Museen der Stadt Wien \& Stadtarchäologie

Paulissen, E., Poesen, J., Govers, G. and De Ploey, J. (1993) The Physical Environment at Sagalassos (Western Taurus, Turkey). A Reconnaisance Survey. In M. Waelkens and J. Poblome (eds.), Sagalassos II. Report on the Third Excavation Campaign of 1992 (Acta Archaeologica Lovaniensia Monographiae 6): 229-248. Leuven: Leuven University Press.

Similox-Tohon, D., Vanneste, K., Sintubin, M., Muchez, P. and Waelkens, M. (2004) Two-dimensional Resistivity Imaging: 
a Tool in Archaeoseismology. An example from Ancient Sagalassos (Southwest Turkey). Archaeological Prospection 11: 1-18.

Tabbagh, J. (2003) Total field magnetic prospection: Are vertical gradiometer measurements preferable to single sensor survey? Archaeological Prospection 10: 75-81.

Telford, W. M., Geldart, L. P. and Sheriff, R. E. (1990) Applied Geophysics (second edition). New York: Cambridge University Press.

Thompson, S. (2004) Side-by-side and back-to-front: exploring intra-regional latitudinal and longitudinal comparability in survey data. Three case studies from Metaponto, southern Italy. In S. E. Alcock and J. F. Cherry (eds), Side-by-Side Survey. Comparative Regional Studies in the Mediterranean World: 65-85. Oxford: Oxbow Books.

Uytterhoeven, I., Martens, F., Mušič, B. and Waelkens, M. (2010) Housing in Hellenistic and Imperial Sagalassos. In S. Ladstätter and V. Scheibelreiter (eds), Städtisches Wohnen im östlichen Mittelmeerraum 4. Jh. v. Chr.-1. Jh. n. Chr., Akten des internationalen Kolloquiums vom 24-27 Oktober 2007 an der Österreichischen Akademie der Wissenschaften (AForsch): 289-307.Wien: Verlag der Österreichischen Akademie der Wissenschaften.

Vandeput, L. and Köse, V. (2004) Pisidien Survey Project: SurveyKampagne 2002 in Pednelissos. In 21. Araştırma Sonuçlart Toplantısl, 26-31 May 2003, Ankara: 345-360. Ankara: Dösimm Basimevi.

Vandeput, L., Köse, V., Zelle, M. and Laufer, E. (2005) Pisidien Survey Project: Survey-Kampagne 2003 in Pednelissos. In 22. Araştırma Sonuçları Toplantısı, 24-28 May 2004, Konya: 335-244. Ankara

Vanhaverbeke, H. and Waelkens, M. (2003) The Chora of Sagalassos. The Evolution of the Settlement Pattern in the Territory of Sagalassos from Prehistoric until Recent Times (Studies in Eastern Mediterranean Archaeology 5). Turnhout: Brepols.
Vermeulen, F., De Dapper, M., Mušič, B., Monsieur, P., Verreyke, M., Carboni, F., Dralans, S., Verhoeven, G., Verdonck, L., Hay, S., Sterry, M., De Paepe, P. and De Seranno, S. (2009) Investigating the impact of Roman urbanisation on the landscape of the Potenza Valley. A report on fieldwork in 2007. BABesch 84: 85-110.

Vionis, A., Poblome, J. and Waelkens, M. (2009) Ceramic continuity and daily life in medieval Sagalassos, SW Anatolia (c. 650-1250). In T. Vorderstrasse and J. Roodenberg (eds), Archaeology of the Countryside in Medieval Anatolia (PIHANS 113): 191-213. Leiden: Nederlands instituut voor het Nabije Oosten.

Waelkens, M. (2004) Fifteen years of archaeological research at Sagalassos. The AAIA Bulletin 2: 26-37.

Waelkens, M. (2006) Sagalassos. In W. Radt (ed.), Stadtgrabungen und Stadtforschung im westlichen Kleinasien, Geplantes und Erreichtes. Internationales Symposion 6./7. August 2004 in Bergama (Türkei) (Byzas 3): 325-358. Istanbul: Ege Yayınları.

Waelkens, M. (2008) Geo and Bio-Archaeology at Sagalasssos and its Territory. In P. Degryse and M. Waelkens (eds), Sagalassos VI. Geo and Bio-Archaeology at Sagalasssos and its Territory: 1-13. Leuven: Leuven University Press.

Waelkens, M., Poblome, J., Vyncke, K., Braekmans, D., Vanhaverbeke, H., Degryse, P., De Cupere, B., Van Neer, W., Marinova, E., Paulissen, E., Lauwers, V., Van Heesch, J., Aydal, S., Mušič, B., Šlapšak, B., Medarič, I., Ekinci, H. A. and Erbay, M. O. (submitted) 'From Düzen Tepe to Sagalassus' or 'Düzen Tepe next to Sagalassus?'. Anatolian Studies.

Walker, R. and Somers L. (1994) Geoplot 2.01. Instruction Manual. Bradford: Geoscan Research.

Yaoguo, L. and Oldenburg, D. W. (1998) Separation of regional and residual magnetic field data. Geophysics, 63(2): 431-439.

Yildırım, B. and Gates, M.-H. (2007) Archaeology in Turkey, 2004-2005. American Journal of Archaeology 111(2): 275356. 